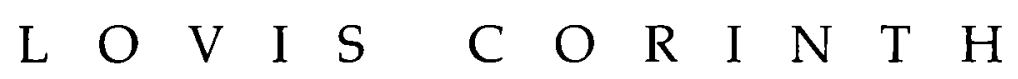


Walter Horn, Founding Editor

James Marrow, General Editor

I The Birth of Landscape Painting in China, by Michael Sullivan

II Portraits by Degas, by Jean Sutherland Boggs

III Leonardo da Vinci on Painting: A Lost Book (Libro A), by Carlo Pedretti

IV Images in the Margins of Gothic Manuscripts, by Lilian M. C. Randall

$\mathrm{v}$ The Dynastic Arts of the Kushans, by John M. Rosenfield

vi A Century of Dutch Manuscript Illumination, by L. M. J. Delaissé

vII George Caleb Bingham: The Evolution of an Artist, and A Catalogue Raisonné (two volumes), by E. Maurice Bloch

viII Claude Lorrain: The Drawings-Catalog and Plates (two volumes), by Marcel Roethlisberger

Ix Venetian Painted Ceilings of the Renaissance, by Juergen Schulz

$x$ The Drawings of Edouard Manet, by Alain de Leiris

xI Theories of Modern Art: A Source Book by Artists and Critics, by Herschel B. Chipp, with contributions by Peter Selz and Joshua C. Taylor

XII After the Hunt: William Harnett and Other American Still Life Painters, 1870-1900, by Alfred Frankenstein

xIII Early Netherlandish Triptychs: A Study in Patronage, by Shirley Neilsen Blum

xiv The Horned Moses in Medieval Art and Thought, by Ruth Mellinkoff

xv Metamorphosis of a Death Symbol: The Transi Tomb in the Late Middle Ages and the Renaissance, by Kathleen Cohen

xvi Franciabigio, by Susan Regan McKillop

xvII Egon Schiele's Portraits, by Alessandra Comini

xviII Manuscript Painting in Paris During the Reign of Saint Louis:

A Study of Styles, by Robert Branner 
xIX The Plan of St. Gall: A Study of the Architecture and Economy of, and Life in a Paradigmatic Carolingian Monastery (three volumes), by Walter Horn and Ernest Born

xx French Gothic Architecture of the 12th and 13th Centuries, by Jean Bony

xxI The Art of Matthew Paris in the Chronica Majora, by Suzanne Lewis

xxII The Literature of Classical Art: The Painting of the Ancients and A Lexicon of Artists and Their Works According to the Literary Sources, by Franciscus Junius (two volumes), edited by Keith Aldrich, Philipp Fehl, and Raina Fehl

xxIII The Armor of Light: Stained Glass in Western France, 1250-1325, by Meredith Parsons Lillich

xxIV Nineteenth-Century Theories of Art, by Joshua C. Taylor

xxv Corinthian Vase-Painting of the Archaic Period (three volumes), by D. A. Amyx

xxvi Picasso's Guernica: History, Transformations, Meanings, by Herschel B. Chipp

xxvII Lovis Corinth, by Horst Uhr

\section{Discovery Series}

I The Devil at Isenheim: Reflections of Popular Belief in Grünewald's Altarpieces, by Ruth Mellinkoff

II The Forgotten Hermitage of Skellig Michael, by Walter Horn, Jenny White Marshall, and Grellan D. Rourke 
$\begin{array}{lllll}\mathrm{L} & \mathrm{O} & \mathrm{V} & \mathrm{I} & \mathrm{S}\end{array}$ 
$\begin{array}{lllllll}C & \mathrm{O} & \mathrm{R} & \mathrm{I} & \mathrm{N} & \mathrm{T} & \mathrm{H}\end{array}$

Horst Uhr 
University of California Press Berkeley and Los Angeles, California University of California Press, Ltd Oxford, England

(c) 1990 by The Regents of the University of California

The works of Lovis Corinth are (c) by Wilhelmine Corinth Klopfer, New York

Library of Congress Cataloging-inPublication Data

Uhr, Horst, 1934-

Lovis Corinth / Horst Uhr.

p. $\mathrm{cm}$. - (California studies in the history of art ; 27)

Includes bibliographical references. ISBN 0-520-06776-2 (alk. paper)

1. Corinth, Lovis,

1858-1925. 2. Artists-

Germany-Biography.

I. Title. Il. Series.

$\mathrm{N} 6888 . \mathrm{C}_{7} \mathrm{U}_{37} \quad 1990$

$759.3-\mathrm{dc} 20$

[B]

Printed in Japan

$\begin{array}{lllllllll}9 & 8 & 7 & 6 & 5 & 4 & 3 & 2 & 1\end{array}$

The paper used in this publication meets the minimum requirements of American National Standard for Information Sciences-Permanence of Paper for Printed Library Materials, ANSI Z39-48-1984. (®) 
To the memory of Auguste and Wilhelm Uhr 


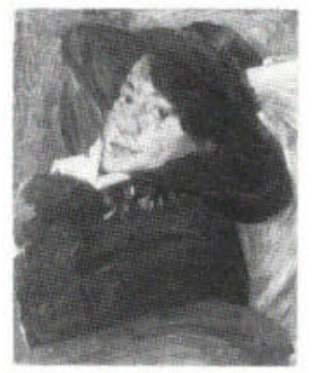

